Ann. Zootech., 1980 29, no h. s., 299-323.

\title{
Chemical methods for predicting the energy and protein value of forages
}

\author{
R. JARRIGE \\ Département de l'Elevage des Ruminants, \\ Centre de Recherches de Clermont-Ferrand, I.N.R.A., \\ Theix, 63110 Beaumont, France.
}

\begin{abstract}
The digestibility of forage organic matter is basically determined by that of the cellwalls and, therefore, by their degree of lignification.

Despite its biochemical inadequacies which have long been known, Weende crude fibre is still universally used to predict feed energy value. Associated with crude protein content, it allows forage digestibility to be predicted with reasonable accuracy (RSD $<4$ ) provided that relationships be set up separately for the first cuts and the regrowths of each forage species.

Many simple methods have been proposed to replace crude fibre which aim at dosing either cellulose, or lignocellulose, or total cell-wall content. The most widely used is Van Soest's acid-detergent fibre which is a lignocellulose residue that is as empirical as crude fibre but has two advantages over the latter : its measurement is quicker and probably more reproductible; it generally allows digestibility prediction to be slightly improved. Lignin is the best chemical predictor of digestibility, when determined by a satisfactory method. Several methods exist but no one can be proposed for the moment for routine analysis because they are too time consuming and/or insufficiently founded. Adding a measurement of hemicellulose and of cellulose to lignin, notably in sequential analysis, improves forage digestibility prediction but at too high a cost.

It would appear that there are no simple chemical treatment which could allow a cellwall residue to be isolated, which is equal or proportional to the non-digestible cell-wall fraction. This can be carried out using rumen liquor microbes or fungal cellulolytic enzymes ("cellulases").

The digestible crude protein content of forages can be predicted accurately from nitrogen content, but it is not a satisfactory criterion for the amount of amino acids supplied directly and indirectly by the forage in the small intestine. To evaluate this amount in the new systems, the forage $\mathrm{N}$ degradability in the rumen and the amount of microbial proteins which result, must be predicted. Many solvents have been proposed to assess $\mathrm{N}$ degradability. Buffer solutions (artificial salivas) are considered to make soluble two out of the three forage nitrogen fractions degradable in the rumen, that is the non-protein constituents and the proteins soluble in the rumen liquor. But a part of the proteins insoluble in the rumen liquor, about 35 per cent (mean) is also broken down by the rumen microbes. Artificial salivas are thus useful at least to describe the main variations in forage $\mathrm{N}$ degradability, for example, through dehydratation or silage additives.

Temporary inadequacies in the knowledge and the prediction of $\mathrm{N}$ degradability, and even more of microbial protein yield, should not prevent present knowledge from being applied with the help of new systems, such as the PDI system.
\end{abstract}




\section{Résumé}

\section{Méthodes chimiques de prévision de la valeur énergétique et azotée des fourrages}

La digestibilité de la matière organique des fourrages est fondamentalement déterminée par la digestibilité des parois cellulaires, et de ce fait, par leur degré de lignification.

En dépit de ses insuffisances biochimiques, connues depuis fort longtemps, la cellulose brute Weende reste encore universellement employée pour prévoir la valeur énergétique des aliments. Associée à la teneur en matières azotées, elle permet d'estimer la digestibilité des fourrages avec une précision relativement satisfaisante (erreur standard inférieure à 4 points), à la condition que les relations soient établies pour chaque espèce fourragère et en distinguant les premiers cycles des repousses.

De nombreuses méthodes simples ont été proposées pour remplacer la cellulose brute. Elles visent à doser la cellulose, la lignocellulose ou les parois totales. La lignocellulose au détergent acide (acid-detergent fibre) de Van Soest est la plus utilisée. C'est un résidu lignocellulosique aussi empirique que la cellulose brute, mais elle présente sur celle-ci deux avantages : son dosage est plus rapide et, sans doute, plus reproductible ; elle permet en général d'améliorer légèrement la prévision de la digestibilité.

La lignine est le meilleur prédicteur chimique de la digestibilité, lorsqu'elle est déterminée par une méthode satisfaisante. Il existe plusieurs de ces méthodes, mais on ne peut pas pour l'instant en proposer une pour les analyses de série, parce qu'elles sont trop longues et (ou) insuffisamment fondées. I'addition du dosage des hémicelluloses et de la cellulose à celui de la lignine, notamment dans les analyses séquentielles, améliore la prévision de la digestibilité des fourrages, mais à un coût trop élevé.

Il n'existe pas, semble-t-il, de traitements chimiques simples qui permettent d'isoler un résidu pariétal égal, ou étroitement lié, à la fraction non digestible des parois. Il faut pcur cela utiliser les microbes du liquide du rumen (digestion in vitro) ou les préparations d'enzymes cellulolytiques fongiques (« cellulases »).

La teneur en matières azotées digestibles des fourrages peut être prévue avec précision, à partir de la teneur en matières azotées. Mais elle n'est pas un critère satisfaisant de la quantité d'acides aminés apportée, directement et indirectement, par le fourrage dans l'intestin grêle. Pour évaluer celle-ci dans les nouveaux systèmes (PDI), il faut prévoir à la fois la fermentescibilité de l'azote du fourrage dans le rumen et la quantité de protéines microbiennes qui sort de ce dernier. De nombreux solvants ont été proposés pour estimer la fermentescibilité. On peut considérer que les salives artificielles (solutions tampons) solubilisent deux des trois fractions azotées des fourrages qui sont dégradées dans le rumen, à savoir les constituants non protéiques et les protéines solubles dans le liquide du rumen; mais une fraction des protéines insolubles dans le liquide du rumen, de l'ordre de 35 p. 100 en moyenne, est aussi dégradée. Les salives artificielles sont donc utiles au moins pour décrire les principales variations de la fermentescibilité des fourrages, par exemple sous l'action de la déhydratation ou des fermentations de l'ensilage.

Les insuffisances actuelles dans la connaissance et la prévision de la fermentescibilité de l'azote des aliments et, plus encore, du rendement de la synthèse des protéines microbiennes, ne doivent cependant pas empêcher de mettre en application les connaissances modernes à l'aide des nouveaux systèmes tels que celui des PDI.

\section{Introduction}

Predicting the nutritive value of forage crops and feedstuffs from their chemical composition is a problem which agricultural scientists have faced for a long time. It has given rise to a great deal of work (see BARNES, 1973 ; Morrison, 1976) and is still a subject for interest in spite of the enzymatic methods which 
have been proposed over the last 20 years (see Osbourn and Siddons, 1980). However in almost all countries the nutritive value is still predicted from the Weende system of analysis which is over one hundred years old and crude fibre determination is required by feedstuff regulations.

We are going to give an overview of the general relationships between the chemical composition of forages and their energy and protein value. Their applications will be illustrated by Demarquilly, Chenost and Sauvant in the next paper.

\section{Digestibility of forage constituents}

As suggested 25-30 years ago (Paloheimo and Paloheimo, 1947 ; FauCONNEAU and JARRIGE, 1954) the chemical constituents of forages should be divided into two groups : the cytoplasmic constituents, or cell contents, and the cell-wall constituents (figure 1).

\section{Cell contents}

The cell contents include water-soluble carbohydrates (sugars, oligosaccharides, fructosans), organic acids, lipids and pigments, proteins, non-protein nitrogenous substances, nucleic acids, phenolic compounds, and most of the inorganic constituents. The proportion of cell contents is higher in cellulosic tissues than in lignified tissues, and higher in leaves than in stems.

Water-soluble carbohydates are fermented entirely in the reticulo-rumen and their apparent digestibility is 100 per cent (JARRIGE and Minson, 1964).
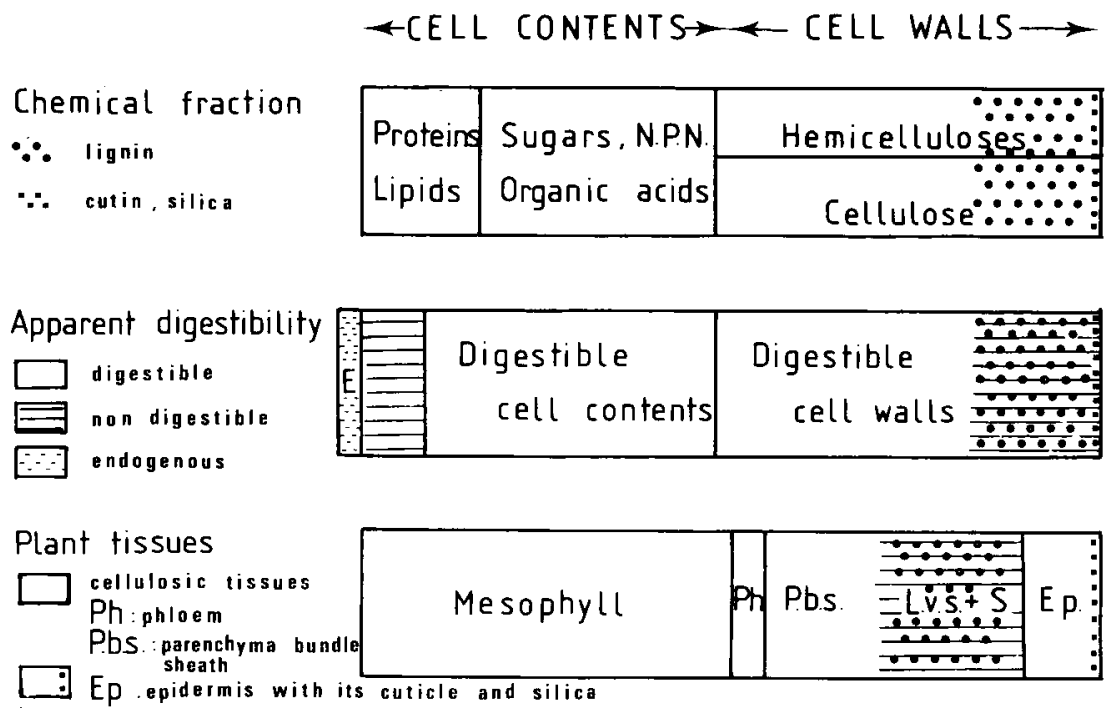

Fon Lignified vascular system and Selerenchyma

FIG. 1. - Model of the contribution of the main chemical and anatomical components to the digestible organic matter of a grass forage $(d \mathrm{O}=0.70)$. 
The true digestibility of crude protein and lipids is very high, generally close to 95 per cent, except in some tannin-rich plants, in overheated hays and silages and in overdried dehydrated forages. However, their apparent digestibility is lower, due to microbial and endogenous residues excreted in the faeces, and is closely related to their content. The apparently digestible crude protein content of normal forages can be predicted very accurately from the crude protein content (see page 316 ).

The true digestibility of cell contents (CC) considered as a nutritional entity is very high and the apparent digestibility rises when percentage of cell contents in the forage is increased. The apparently digestible cell contents (DCC) have been shown to be a linear function of the cell contents measured as dry matter soluble in VAN SOEST neutral-detergent solution:

$\mathrm{DCC}=0.98 \mathrm{CC}-12.9(\mathrm{R}=0.99)$ for 19 forages (VAN SoEST, 1967),

$\mathrm{DCC}=1.01 \mathrm{CC}-12.9(\mathrm{RSD} \pm 1.4)$ for 35 forages (DEINUM, 1971),

$\mathrm{DCC}=0.957 \mathrm{CC}-11.1(\mathrm{RSD} \pm 1.48)$ for 54 forages (OSBOURN et al., 1976), $\mathrm{DCC}=1.24 \mathrm{CC}-20.7$ (RSD \pm 3.0 ) for 101 diets (AERTs et al., 1978).

This correlates with the apparently non-digestible cell content (NDCC) calculated by substracting the non-digestible cell-walls (NDCW) from the nondigestible organic matter (fig. 5). NDCC can be considered fairly constant, at least in fresh forages, varying from 12 to 15 per cent of the organic matter (i.e. 11.5 to 14 per cent of dry matter), mainly with the apparently non-digestible protein content.

Table 1 : RELATIONSHIP BETWEEN (1) CELL-WALL DIGESTIBILITY (d $C W \times 100)$ AND LIGNIN (L), (2) ORGANIC MATTER DIGESTIBILITY (d $0 \times 100)$ AND CELL-WALIS DIGESTIBILITY ( $\mathrm{d}$ CW $x$ 100) AND (3) NON DIGESTIBLE ORGANIC MATTER (DOM) AND NON DIGESTIBLE CELL-WALL (NDCW) (1)

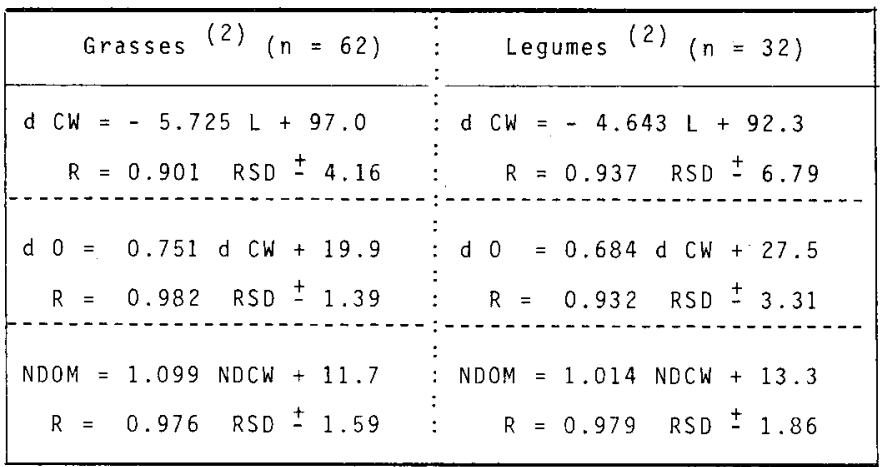

(1) Cell-walls = hemicellulose + cellulose + lignin (corrected for its protein content), measured according to the sequential analysis of JARRIGE (1961) and expressed as percent of organic matter(see table 5).

(2) Forages : 30 rye grass and 32 cocksfoot, 18 lucerne, 11 red clover and 7 white clover (see table 5). 


\section{Cell-walls}

Plant cell-walls are made up of structural polysaccharides with lesser amounts of lignin and cutin, traces of protein (extensin) and silica. The structural polysaccharides may be divided into three main groups (see JARRIGE, 1963 and BAILEY, 1973) : cellulose, hemicelluloses of which xylans are the most important, and pectic substances. Hemicelluloses and pectic substances are frequently grouped under the general heading of hemicellulose.

The extent of cell-wall degradation by the microorganisms of the reticulorumen (and of the large intestine) is extremely variable. The thin cell-walls of the cellulosic tissues (mesophyll, phloem) are completely degraded as shown by their absence in the faeces (GRENET, 1966). In contrast, the thick cell-walls that are incrusted with lignin (sclerenchyma, xylem) or protected with a thick cuticle (epidermis), are entirely undigested or degraded to a low extent as shown by microscopic techniques (AKIN, 1979).

For nutritional purposes, the forage cell-wall content can be divided diagrammatically into two fractions (JARRIGE and Minson, 1964, Minson 1976) (fig. 1) :

1) one fraction that may be regarded as potentially fully digestible (DCW). It comprises the fraction of the forage cell-wall polysaccharides that is not protected by lignin, cutin or other structural inhibitors ;

2) a fraction that may be regarded as completely indigestible (NDCW). It comprises lignin and cutin and the fraction of the forage cell-wall polysaccharides that they protect from degradation. Xylans can be linked to lignin and thus hemicelluloses are clearly less digestible than pectic substances (arabinose) and cellulose (JARRIGE and Minson, 1964). However the non-digestion of cell-wall polysaccharides cannot be ascribed entirely to lignification. It can be due in addition to other factors such as the cristallinity of the polysaccharides and their acetylation.

The NDCW fraction increases as the plant matures due to the increase in the proportion of stems and lignified tissues. Thus the apparent digestibility of plant cell-walls decreases with advancing maturity, from up to 90 per cent in young leafy herbage down to less than 40 per cent in straws. It is closely related to the lignin content (table 1 - fig. 2), more closely than to the cell-wall content itself.

As the apparently non digestible cell contents remain roughly constant the apparently non-digestible organic matter, or ballast, depends strictly on the non-digestible cell-wall content, the regression coefficient being remarkably similar (from 1.0 to 1.15 ) for different forages (table 1 - fig. 5). Hence the apparent digestibility of herbage organic matter is closely related to the apparent digestibility of its cell-walls (fig. 3). However there are differences between species, families and cut numbers. For example, at equal concentrations of lignin, legumes have lower NDCW than grasses (fig. 4) and therefore higher organic matter digestibility. This is because legumes have lower contents of total cell-walls, especially of hemicelluloses, and also because their lignins probably interact chemically to a lesser extent with hemicellulose than those of grasses (GoRdon, 1975).

The problem of estimating forage digestibility is essentially that of estimating its indigestible cell-wall content.

It must be mentionned that the apparent digestibility of cell-wall polysaccharides can be less than the potential when the extent of the microbial degradation 


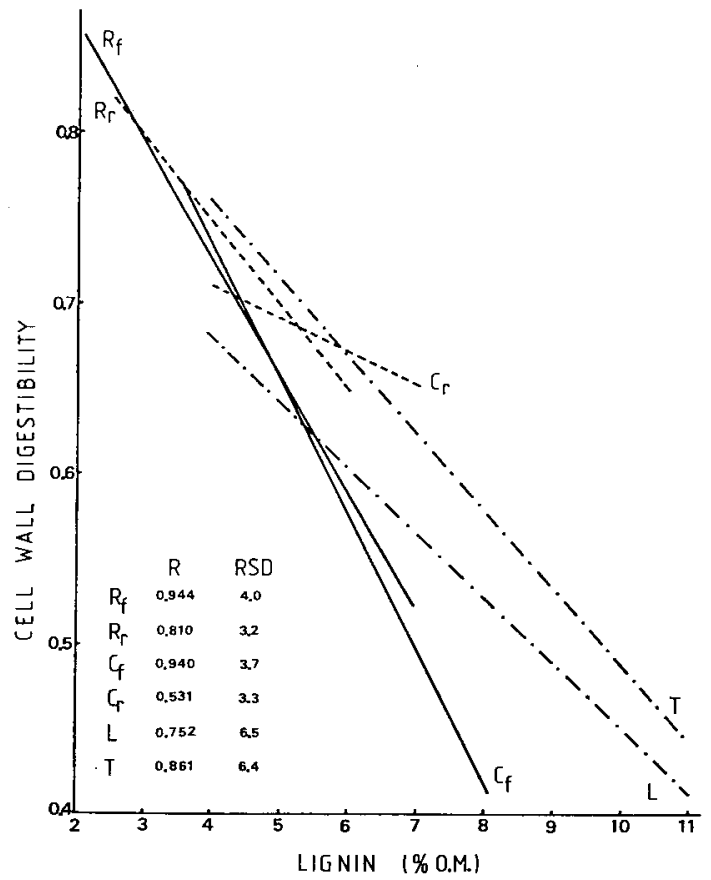

FIG. 2. - Linear relationship between the digestibility of cell walls (Hemicelluloses + Cellulose + Lignin) and the lignin content (see table 5). $\mathbf{R} f$ : rye grass, first growth; $\mathbf{C f}$ : cocksfoot, first growth; $\mathbf{L}$ : lucerne. $\mathrm{R} r$ : rye grass, regrowths: $\mathrm{Cr}$ : cocksfoot, regrowths; $\mathbf{T}$ : clovers.

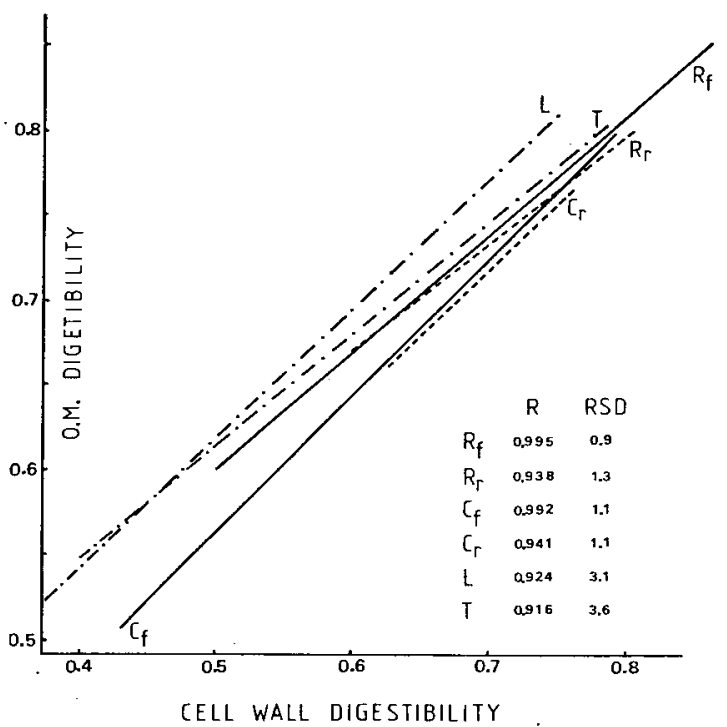

FIG. 3. - Relationship between the digestibility of organic matter and the digestibility of cell walls (Hemicelluloses + Cellulose + Lignin) (see table 5).

$\mathbf{R} f$ : rye grass, first growth; $\mathbf{C f}$ : cocksfoot, first growth; $\mathbf{L}$ : lucerne.

$\mathrm{R} r$ : rye grass, regrowths; $\mathrm{Cr}$ : cocksfoot, regrowths; $\mathrm{T}$ : clovers. 


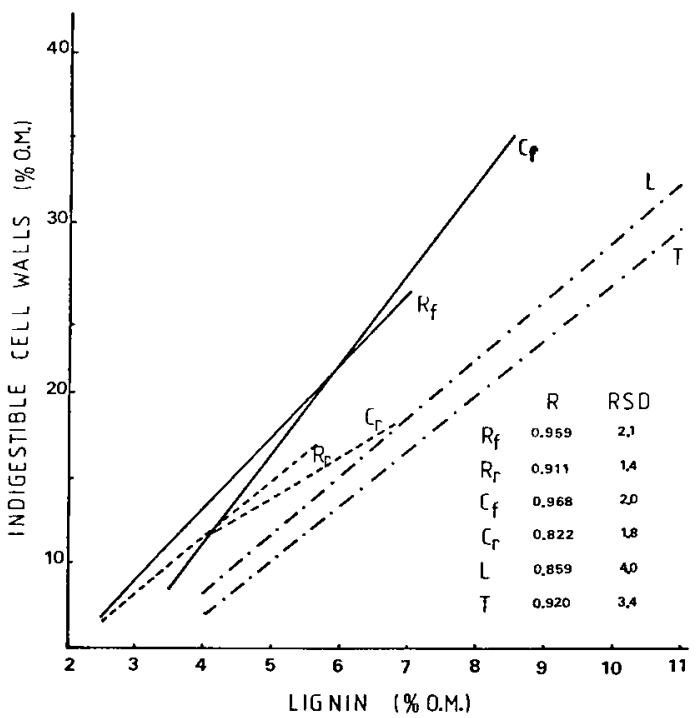

Fig. 4. - Relationship between the indigestible cell walls and lignin (see table 5).

$\mathrm{R} f$ : rye grass, first growth; $\mathrm{C} f$ : cocksfoot, first growth; $\mathrm{L}$ : lucerne.

$\mathrm{R} r$ : rye grass, regrowths; $\mathrm{C} r$ : cocksfoot, regrowths; $\mathrm{T}$ : clovers.

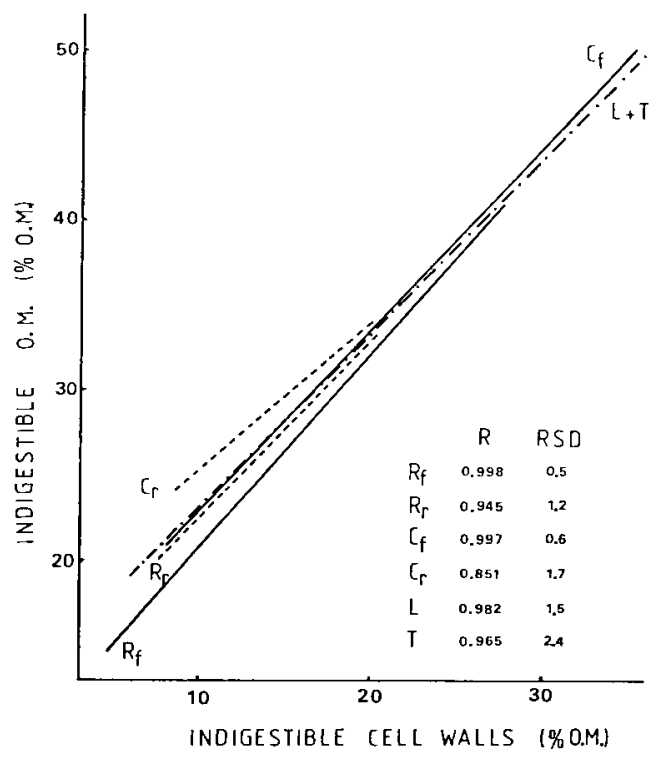

FIG. 5. - Relationship between the indigestible organic matter and the indigestible cell walls.

$\mathrm{R} f$ : rye grass, first growth; $\mathrm{C} f$ : cocksfoot, first growth; $\mathrm{L}:$ lucerne;

$\mathrm{Rr}$ : rye grass, regrowths; $\mathrm{Cr}$ : cocksfoot, regrowths; $\mathrm{R}$ : clovers.

(The relationship for lucerne and clovers are quite identical.) 
in the rumen is reduced. This can occur when the retention time of forage in the rumen is reduced by high levels of intake or by finely grinding forage and when the cellulolytic activity of the microbes is depressed by a deficiency in degradable nitrogen and in minerals and (or) by a low rumen $\mathrm{pH}$ (starchy diets).

\section{Prediction of the energy value of forages}

The metabolizable energy content of forages is closely linked to the apparent digestibility of organic matter (d 0$)$, which is most frequently measured on wethers. In the new energy system proposed in France, (VERMOREL, 1978), the ME content is estimated from 1) the gross energy content of organic matter, which is related to the crude protein content, 2) the digestibility of energy deduced from d 0 (DEMARQuilly et al., 1978) and 3) the relation between digestible energy and metabolizable energy which depends on crude fibre content, protein content and the level of feeding.

\section{Crude fibre}

Crude fibre measured in the old Weende analysis system is an empirical residue obtained by boiling the feed successively with diluted acid and diluted alkali. These hydrolysis dissolve almost all the cell contents, the major part (60-80 per cent) of hemicelluloses, a small fraction of cellulose and a rather variable fraction of lignin, which is much higher in grasses (60-90 per cent) than in legumes (20-50 per cent) (see for example Norman, 1935).

Hence, crude fibre is a cellulosic residue composed mainly of cellulose (7090 per cent) with lignin (5-20 per cent) and residues of hemicellulose (5-10 per cent) and protein (1-3 per cent). The crude fibre content should be considered as an overestimation of the cellulose content. It is closely related to the sum cellulose + lignin within each plant group (fig. 6), especially for grasses $(R=0.98$, RSD $<1.0$ for rye grass and cocksfoot). The ratio crude fibre : total cell-walls is 55-60 per cent in grasses and 60-70 per cent in legumes and increases with plant maturity. The apparent digestibility of crude fibre is 0 to 0.10 lower than that of cellulose in grasses (JARRIge and Minson, 1964) and 0.15 to 0.20 in legumes. In many forages, crude fibre can be as digestible or even more digestible than the nitrogen-free extract which contains the major part of hemicellulose and a fraction of lignin together with cytoplasmic components other than nitrogenous and ether extractable substances. Thus, crude fibre does not mean indigestible cell-walls.

The crude fibre content, as well as the cellulose content, is not the prime factor of the indigestible cell-wall content and thus, of the organic matter digestibility. However, it is associated with the proportion of stems and with the cell-wall content, and is generally correlated with the lignin content. These associations are very close during the first growth of each plant and the organic matter digestibility of the plant can be predicted satisfactorily from its crude fibre content, particularly when considered with nrotein content (tabla 5). However, the association between crude fibre and cell-wall and lignin contents can differ between first growth and regrowths, 


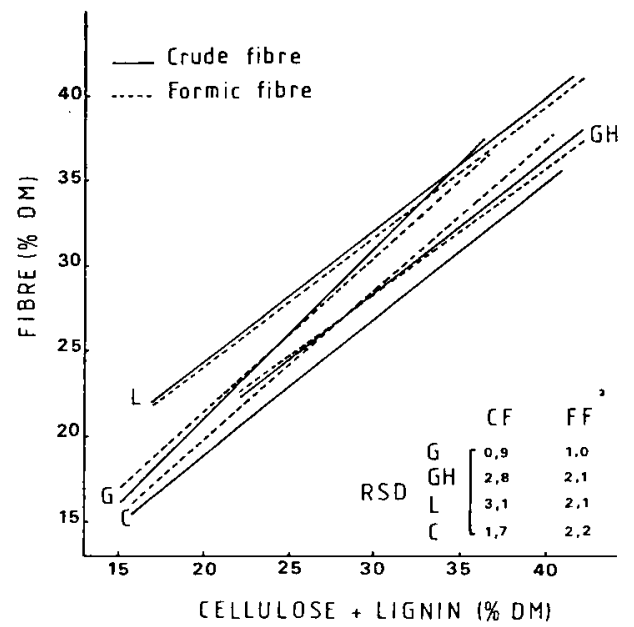

FIG. 6. - Linear relationship between crude fibre or formic fibre and the sum cellulose + lignin (see table 5).

$\mathrm{G}: 62$ rye grass and cocksfoot.

GH : 34 grasses +15 meadow hays.

$\mathrm{L}: 35$ lucerne.

C : 18 clovers.

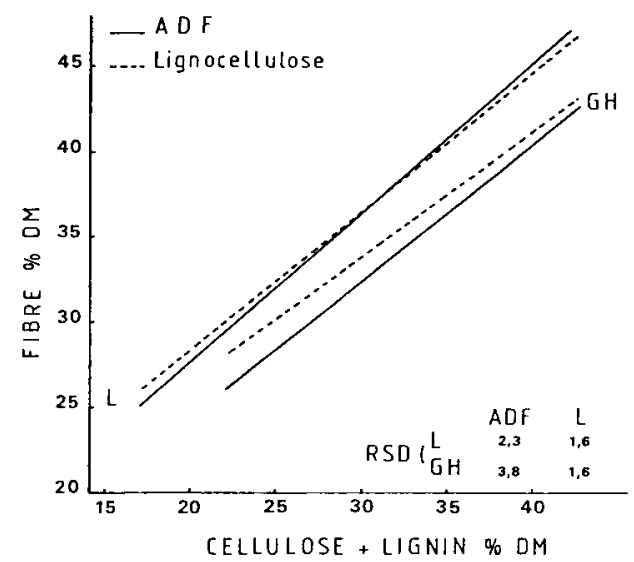

FIG. 7. - Linear relationship between acid detergent fibre (VAN SOEST) or lignocellulose (JARRIGE) and the sum cellulose + lignin (see table 5).

$\mathrm{L} \quad$ : 35 lucerne.

$\mathrm{GH}: 34$ grasses +15 meadow hays. 
between grasses and legumes, between species of the same family and between fresh and conserved crops. Separate regression equations are required for each group of forages (DEMARQUILLY et al., 1980).

The shortcomings of the crude fibre method have been known for a long time. Other methods have been proposed, with different aims that are not always compatible : 1) to obtain chemical entities ; 2) to save time and improve reproducibility or, 3) to improve forage digestibility prediction.

These methods can be divided into three groups : 1) simple methods as alternatives to crude fibre ; 2) lignin methods, and 3) summative analysis.

\section{Simple methods alternative to crude fibre}

\section{Acid fibres or lignocelluloses}

The alkaline digestion of the Weende procedure removes protein but dissolves a considerable and variable fraction of lignin. To overcome this loss of lignin, fibre methods using only acid digestion (but with a stronger acid, 5 per cent or $\mathrm{nH}_{2} \mathrm{SO}_{4}$ ) were suggested by Norman (1935) and Hallsworth (1950) and have been worked out later on (WALKER and HePBURN, 1955; JARRIGE, 1962) (table 2). VAN SOEST (1963) added a detergent to the acid solution in order to dissolve more protein and to obtain a fibre residue of lower nitrogen content. The detergent facilitates the solution of fat and allows the preextraction of fat to be eliminated. This is probably why the acid-detergent fibre (ADF) has been widely used.

Cellulose and lignin can be thought to be almost completely recovered in the acid-detergent fibre, together with a variable fraction of the hemicelluloses

Table 2 : SOME ALTERNATIVES TO CRUDE FIBRE IN THE ANALYSIS OF FORAGES

\begin{tabular}{|c|c|c|c|c|}
\hline & $\begin{array}{l}: \text { Name of the } \\
\text { :residue obtained }\end{array}$ & $\begin{array}{l}\vdots \\
\vdots \\
\vdots\end{array}$ & $\begin{array}{l}: \text { Fat } \\
\text { :extraction: }\end{array}$ & Au thors \\
\hline $\begin{array}{l}\text { CELLULOSE } \\
\text { RESIDUES }\end{array}$ & $\begin{array}{l}: \text { Cellulose } \\
\vdots \text { Cellulose } \\
\vdots \\
\vdots \text { Cellulose } \\
\vdots \text { Formic fibre } \\
\vdots\end{array}$ & $\begin{array}{l}\vdots \mathrm{H} \mathrm{NO}_{3}-\text { ethanol }(1: 4) \\
\vdots \\
\vdots \\
\mathrm{H} \mathrm{NO}_{3}-\mathrm{CH}_{3} \mathrm{COOH} \\
\vdots \\
\mathrm{Na}_{2} \mathrm{SO}_{3} ; \mathrm{NaCClO}\end{array}$ & $\begin{array}{l}0 \\
0 \\
+\end{array}$ & $\begin{array}{l}: \\
: \text { KURSCHNER and HOFFER } \\
\vdots \\
: \text { KURSCHNER and HANAK } \\
\vdots \\
: \text { NORMAN } \quad(1930) \\
\vdots \\
: \text { and JENKINLEMET } \\
: \quad(1933) \\
\quad(1942)\end{array}$ \\
\hline $\begin{array}{l}\text { LIGNOCELLULOSE } \\
\text { RESIDUES }\end{array}$ & $\begin{array}{l}: \text { Normal-acid fibre } \\
: \\
\vdots \text { Lignocellulose } \\
\vdots \text { Acid-detergent } \\
\vdots \text { fibre }\end{array}$ & $\begin{array}{l}\vdots \text { In } \mathrm{H}_{2} \mathrm{SO}_{4} \\
\vdots 1 \text { hour } \\
\vdots \\
5 \% \mathrm{H}_{2} \mathrm{SO}_{4} \\
3 \text { hours } \\
\vdots 1 \mathrm{H}_{2} \mathrm{SO}_{4}+\text { detergent } \\
: 1 \text { hour }\end{array}$ & $\begin{array}{l}\vdots \\
\vdots \\
\vdots \\
\vdots \\
\vdots\end{array}$ & $\begin{array}{l}: \text { WALKER and HEPBURN } \\
\vdots \\
: \text { JARRIGE }(1961) \\
\vdots \\
\vdots \\
\vdots\end{array}$ \\
\hline $\begin{array}{l}\text { CELL-WALLS } \\
\text { RESIDUES }\end{array}$ & $\begin{array}{l}: \text { Membrane substances } \\
\vdots \\
: \text { Neutral-detergent } \\
: \text { fibre }\end{array}$ & $\begin{array}{l}: 0.05 \mathrm{n} \mathrm{HCl} \\
: 30 \text { minutes } \\
: \text { water + detergent } \\
: 1 \text { hour }\end{array}$ & $\vdots$ & $\begin{array}{l}\text { PALOHEIMO (1945) } \\
\vdots \\
: \text { VAN SOEST and WINE } \\
: \quad(1967)\end{array}$ \\
\hline
\end{tabular}

(1) This method is frequently ascribed to CRAMPTON and MAYNARD (1938) who proposed to use it, together with a lignin determination, in the analysis of feeds. 
and pectic substances which is greater in legumes $(30-45$ per cent) than in grasses (15-30 per cent) (KIM et al., 1967; BAILEY and ULYATT, 1970; RiQueT, 1979), a fraction of ash including all the silica (VAN SOEST and WINE, 1968), protein residues... Thus the acid-detergent fibre is not a pure lignocellulose. It is higher than the sum cellulose + lignin (figure 7). In addition to cellulose (45-65 per cent of the ADF) and lignin (10-20 per cent), it contains hemicelluloses and pectic residues (10-20 per cent), protein residues (1-6 per cent), ash and an undetermined fraction (table 3). Like the crude fibre, the ADF of legumes has a higher lignin content than that of grasses and a lower cellulose content (Colburn and Evans, 1967 ; Riquet, 1979) (table 3). The ash content of ADF

Table 3 : COMPOSITION OF THE ACID-DETERGENT FIBRE (Data of RIQUET (1979) on 13 forages and JARRIGE (unpublished) on 14 forages.

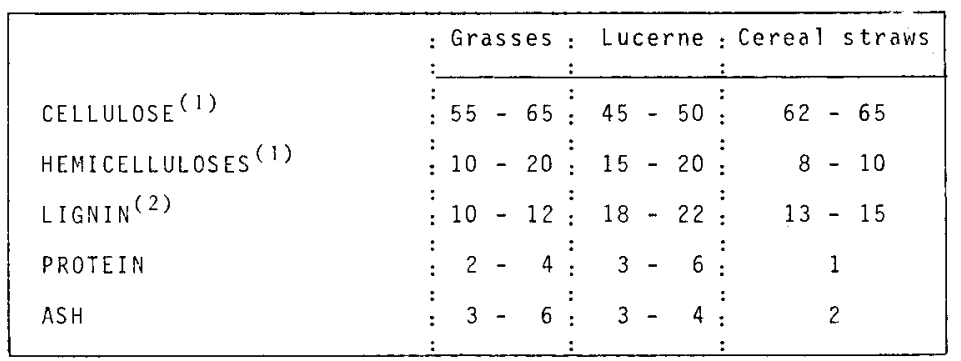

(1) Hemicelluloses (including pectic substances) and cellulose are measured by the reducing power of their sugars in the hydrolysates by dilute $\mathrm{H}_{2} \mathrm{SO}_{4}$ and $72 \% \mathrm{H}_{2} \mathrm{SO}_{4}$ sequentially. Lignin is corrected for its protein content.

(2) The differences in the lignin content of A D F are in agreement with the data of COLBURN and EVANS (1967) (10.6\% for grasses and $16.3 \%$ for lucerne and lucerne grass mixtures) and of THEANDER and AMAN (1980).

is quite variable and can exceed 10 per cent in some silages, probably in relation with silica content. Almost all ash derived from soil contamination is recovered in ADF (AERTs et al., 1978). The $\mathrm{N}$ content of ADF (like that of other acidfibres) is increased by MAILlaRD reactions in forages that have undergone heating either spontaneous (silages...) or artificial which was suggested to be a sensitive assay for this non-enzymic browning (VAN SOEST, 1965). Extending hydrolysis duration with acid-detergent dissolves more hemicelluloses and pectic substances (BAILEY and ULYATT, 1970) and other substances (protein), resulting in a lower yield of ADF (CLANCY and WILSON, 1966 ; MC LEOD and Minson, 1972) as was previously shown with acid alone (JARRIGE, 1961).

There are very few comparisons between ADF and crude fibre as predictor of forage digestibility (table 4). In most of them, ADF has allowed slightly more accurate predictions than crude fibre, as have the non-detergent sulfuric fibres such as JARRIGE's lignocellulose (table 5). This improvement is probably due to the fact that ADF and other sulfuric fibres contain all lignin. Slightly better accuracy has been achieved for some forage groups, but not for all, by extending hydrolysis duration to 2 hours (CLANCY and WILSON, 1966) or more (MC LEOD and Minson, 1972), of by increasing the acid-strength (MC LFOD and Minson, 1972). Correcting the ADF for its ash content has improved the 
Table 4 : COMPARISON BETWEEN VAN SOEST'S TECHNIQUES AND CRUDE FIBRE IN THE ACCURACY OF PREDICTING FORAGE DIGESTIBILITY

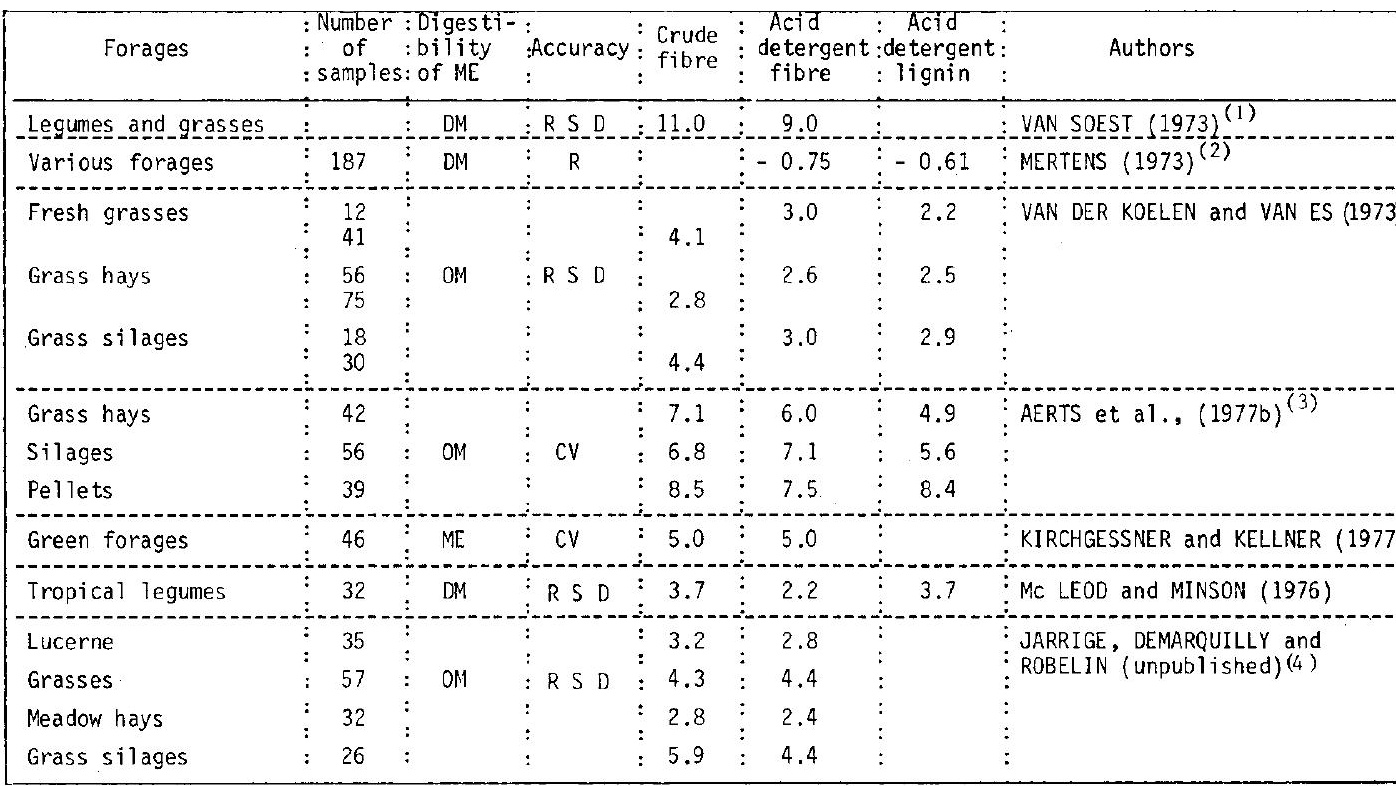

(1) Quoted by VAN SOEST and ROBERTSON (1980)

(2) Quoted by VAN SOEST and MERTENS (1977)

(3) Permanganate lignin in $\mathrm{ADF}$. Lignin and $A D F$ are ash.free

(4) Crude protein content is included in the regression equation. A D F is ash-free

accuracy for some species but decreased it for others (Mc LEOD and Minson, 1972 ; JARRIGE, unpublished). Therefore, improvements in the accuracy of predicted digestibility should be achieved by selecting the optimum conditions for each forage group (species...). However they seem to be much too time-consuming to warrant any change in the analytical condition proposed by VAN SOEST.

Other one-step hydrolytic treatments have been proposed to obtain a lignocellulosic residue, such as 80 per cent formic acid (GuILlEMET and PRECEPTIS, 1942, Guillemet and JACQUOT 1943) and 5 per cent KOH (Kesting, 1978). It is noteworthy that the formic fibre content, which is very close to the crude fibre content (fig. 6), is equal to crude fibre when used to predict digestibility of most of the forages (table 5).

\section{Total cell-walls}

As early as the end of the last century, attempts were made to separate the total cell-wall constituents from the cell contents. Water, lipid solvents (ethanol, ether...), enzyme preparations, diluted alkaline or acid solutions were used. For example, Paloheimo and Paloheimo (1948) prepared a residue called " total membrane substances » after ethanol-benzene extraction and boiling in $0.05 n \mathrm{HCl}$ and corrected it for its nitrogen and ash contents (table 2).

The neutral detergent procedure proposed by VAN SOEST and WINE (1967) is a much shorter method. The neutral-detergent fibre (NDF) approximates the plant cell-wall constituents. However, it contains residues of cell contents, mainly nitrogenous substances ( 3 to 15 per cent of NDF) and ash. Moreover, a fraction 
Table 5 : ACCURACY (RSD) IN THE PREDICTION OF ORGANIC MATTER DIGESTIBILITY FROM DIFFERENT FIBRE RESIDUES AND SEQUENTIAL ANALYSIS OF CELL WALLS (in addition to crude protein)

\begin{tabular}{|c|c|c|c|c|c|c|c|c|c|c|c|c|c|c|}
\hline & $\begin{array}{l}\vdots \\
: \text { Number } \\
\vdots \\
\vdots \\
:\end{array}$ & $\begin{array}{l}\text { : FIBR } \\
: \text { Cruie } \\
\vdots \text { Eibre } \\
\vdots \\
\text { Protei }\end{array}$ & & $\begin{array}{l}\text { ESIDU } \\
\text { igno- } \\
\text { ellu- } \\
\text { ose } \\
\text { rotei }\end{array}$ & & $\begin{array}{l}\text { Formic } \\
\text { fibre }\end{array}$ & & $\begin{array}{l}\text { lemi- } \\
\text { cellu- } \\
\text { loses } \\
\text { Protei }\end{array}$ & & $\begin{array}{l}\text { UENTIA } \\
\text { rose } \\
\text { rotein }\end{array}$ & \begin{tabular}{l} 
AL ANALYS \\
\hdashline$:$ ignit \\
$\vdots \quad(2)$ \\
$\therefore$ \\
n:Proteir
\end{tabular} & $\begin{array}{l}\text { SIS OF } \\
: \text { Cel1- } \\
\text { :walls } \\
\pm \\
\text { :Prote }\end{array}$ & & $\begin{array}{l}\text { L-WALLS (1) } \\
\text { emicellubases } \\
\text { ellu lose } \\
\text { ignin (2) } \\
\text { rotein }\end{array}$ \\
\hline Rye-grass : 1st growth & $: \quad 17$ & $: 2.6$ & : & 2.3 & : & 2.6 & : & 2.9 & : & 2.7 & $: 2.3$ & $: 2.5$ & : & 1.9 \\
\hline Rye-grass : regrowths & 13 & 2.2 & $:$ & 2.2 & : & 2.2 & : & 2.3 & : & 2.2 & 1.8 & $\vdots 2.2$ & $\vdots$ & 2.1 \\
\hline Rye-grass : all samples & 30 & 2.8 & : & 2.6 & : & 2.8 & : & 3.2 & : & 3.0 & 2.3 & $: 2.5$ & : & 2.3 \\
\hline Cocksfoot : 1st growth & 19 & 3.9 & : & 3.4 & : & 3.9 & : & 3.9 & : & 3.8 & 1.8 & $\vdots 2.8$ & : & 1.9 \\
\hline Cocksfoot : regrowth & 13 & 2.8 & : & 2.7 & : & 2.9 & : & 2.7 & : & 2.9 & 2.6 & $: 1.9$ & : & 2.0 \\
\hline Cocksfoot : a 11 samples & 32 & 4.1 & : & 3.6 & . & 4.2 & : & 4.4 & : & 4.1 & 2.8 & $: 3.3$ & : & 2.7 \\
\hline Meadow fescue, (12) Timothy. (8) & 20 & 3.9 & : & 4.1 & : & 4.3 & : & 4.9 & : & 4.4 & 3.9 & $: 4.2$ & : & 2.9 \\
\hline Italian Rye-grass & 14 & 2.5 & : & 2.4 & : & 2.4 & : & 2.9 & : & 2.8 & 2.0 & $: 2.8$ & $:$ & 2.4 \\
\hline Grasses : a11 samples & 96 & 4.2 & : & 4.1 & : & 4.3 & : & 4.9 & : & 4.6 & 3.0 & $: 4.1$ & : & 3.0 \\
\hline Lucerne & 35 & 3.2 & : & 2.8 & & 2.9 & & 3.8 & & 3.4 & 2.8 & $: 3.1$ & $:$ & 2.7 \\
\hline Red clover (11), white clover (7): & 18 & 4.0 & : & 4.0 & : & 4.6 & ; & 4.8 & : & 4.7 & 3.8 & $: 4.0$ & : & 3.6 \\
\hline Legumes : a11 samples & 53 & 3.4 & : & 3.2 & 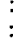 & 3.5 & & 5.2 & & 4.0 & 3.4 & $\vdots 3.7$ & : & 3.0 \\
\hline Meadow hays & 31 & 3.5 & : & 3.2 & : & 3.8 & : & 4.2 & : & 4.0 & 3.4 & $\begin{array}{l}: 3.9 \\
:\end{array}$ & : & 2.8 \\
\hline
\end{tabular}

(1) Sequential analysis according to JARRIGE (1961) including water, ethanol - benzene, $\mathrm{H}_{3}$ SO, $5 \mathrm{p} 100$ ( 3 hours) $\mathrm{H}_{2} \mathrm{SO}_{4} 72 \mathrm{p} 100$. Hemicelluloses and cellulose are measured by the reducing power ( $x$.9) of sugars in the hydrolysates. Lignin is corrected for its protein content. Cell walls are the sum Hemicelluloses + Cellulose + Lignin, and do not include uronic acids.

Rye grass and cocksfoot from Hurley analysed by JARRIGE and MINSON (1964); other grasses and legumes from Theix (DEMARQUILLY et al., )

(2) Regressions $y=a+b x+c x^{2}$

of the cell-wall polysaccharides, especially pectic substances, is dissolved by the neutral-detergent and even a fraction of lignin (BAILEY and UlyatT, 1970; Colburn and Evans, 1967).

The neutral-detergent fibre is generally a less efficient predictor of forage digestibility than ADF, or even crude fibre (VAN SOEST and MERTENS, 1977). In contrast, it predicts the voluntary matter intake better. The NDF is valuable to measure the dietary fibre (i.e. polymeric substances resistant to animal digestive enzymes) in feedstuffs for non-ruminants.

\section{Lignin methods}

As lignin is the prime factor of cell-wall indigestibility (table 1), many attempts have been made to use the lignin content to predict forage digestibility.

By far, the majority of studies on lignins have been carried out on wood lignins. Methods of determining lignin in forage crops are adapted from those on wood (see MoRrison, 1976). Since the work of KLASON, most of them have been based on the removal of cellulose from a lignocellulose residue with 72 per cent sulfuric acid, leaving an acid-insoluble residue which is estimated gravimetrically and called crude lignin. This crude lignin can contain humin products resulting from the condensation of protein and non-cellulosic carbohydrate hydrolysis products. The methods differ in preliminary treatments applied before hydrolysis with 72 per cent $\mathrm{H}_{2} \mathrm{SO}_{4}$ to remove these two groups of compounds (JourNET and JARRIGE, 1962). The so-called true lignin is obtained after correcting the crude lignin for its nitrogen 
contents or removing humins (with an acid-detergent solution in the method of Christian (1971). An alternative procedure to these sulfuric lignins is to remove the lignin rather than the cellulose from the lignocellulose residue. Methods based on this principle have been developped using permanganate (VAN SoEST and WINE, 1968) or triethylene glycol (EDWARDS, 1973). The weight-loss is calculated as lignin.

All methods to determine lignin are more or less empirical. There is some uncertainty as to whether they measure all the lignin and only the lignin. Lignin is defined by the method used to isolate it. Moreover a pure lignin preparation may not be better than a crude preparation to predict forage digestibility.

KLASON lignins (without detergent) have generally been found to predict digestibility with a distinctly lower error than crude fibre and its alternatives (Kivimae, 1959 ; Sullivan, 1964 ; Muller et al., 1970 ; Van der Koelen and VAN Es, 1972; JARRIGE et al., table 5). Their superiority is maximum when they are applied to groups of forages including different species and different cuts. However separate predicting equations are required for grasses and legumes. Grasses have a lower organic matter digestibility than legumes with the same lignin content as shown in the following equations (JARRIGE et al., table 5) relating the digestibility of organic matter $(\mathrm{d} 0)$ to the true lignin (TL) and crude protein (CP) content (as per cent of organic matter) :

$\begin{array}{lll}\text { Rye grass (30) } d 0=86.0+0.243 \mathrm{CP}-3.662 \mathrm{TL} & \mathrm{RSD} \pm 2.30 . \\ \text { Cocksfoot (32) } d 0=89.2+0.122 \mathrm{CP}-4.083 \mathrm{TL} & \mathrm{RSD} \pm 2.92 . \\ \text { Grasses } & \text { (96) } d 0=87.8+0.172 \mathrm{CP}-3.796 \mathrm{TL} & \mathrm{RSD} \pm 3.06 . \\ \text { Lucerne } & \text { (35) } d 0=73.4+0.601 \mathrm{CP}-2.792 \mathrm{TL} & \mathrm{RSD} \pm 2.79 .\end{array}$

The detergent sulfuric lignin of VAN SOEST (1963) appears to predict digestibility with a lower accuracy than the non-detergent sulfuric lignins. The errors (RSD) were 5.2 and 3.1 respectively with 14 samples of grasses and legumes (JARRIGE, unpublished) and 5.0 and 3.1 with 50 samples of tropical grasses (MCLEOD and Minson, 1971). With the latter samples the errors were 3.9, 4.5 and 2.4 with the lignin content determined by the methods of VAN SOEST and WINE (1968), EDWARDS (1973) and Christian (1971) respectively (MC LEOD and Minson, 1974). This lower accuracy of lignins determined on acid-detergent fibre is related to a more narrow range of variation, especially because the values for mature forages are much lower than those obtained with the non-detergent sulfuric methods. Detergent treatments, even neutral detergents, are likely to dissolve some lignin or to make it accessible to the 72 per cent $\mathrm{H}_{2} \mathrm{SO}_{4}$ hydrolysis. The permanganate lignin is higher than the sulfuric lignin measured in the same ADF (VAN SoEST and WINE, 1968; DEINUM, 1971) and is better related to digestibility (MCLEOD and Minson, 1974; AERTs et al., 1977a). The detergent permanganate lignin had been found to predict digestibility with a lower error than ADF in some comparisons (VAN DER Koelen and VAN Es, 1973; AERTs et al., $1977 b$ ) but not the sulfuric lignin (VAN Soest and Mertens, 1977) (table 4).

All these lignin methods are time-consuming. A much shorter method was adapted from wood analysis by MORRISON (1972). After prior removal of interfering phenolic materials, the cell-walls are dissolved in acetyl bromide in acetic acid and lignin is measured spectrophotometrically at $280 \mathrm{~nm}$. The correlation coefiicient with the digestibility of hays and silages would be higher than for modified acid-detergent fibre or lignin. (MORRISON, 1973). 


\section{Summative and sequential analysis}

Following the suggestion of Norman (1935) and Crampton and Maynard (1938) to replace crude fibre by the determination of cellulose and lignin, many authors have proposed to measure the main carbohydrate fractions : soluble carbohydrates, hemicelluloses and pectic substances, anhydro-uronic acid, cellulose and lignin. This can be done on separate samples (CHARLEY-LERY et al., 1952; GAILlARD, 1958 ; WAITE and GORROD, 1959) or on the same sample following a sequential analysis (HARwood, 1958 ; JARrige, 1961 ; Deriaz, 1961 ; Bailey, 1964 ; SALO, 1965 ; SouTHGATE, 1969). In all these sequential systems of analysis, the carbohydrate fractions are estimated from sugar determination in the extracts.

As shown by our data summarized in table 5 , the digestibility of most forage groups can be predicted accurately from their content in hemicelluloses, cellulose, lignin and protein (the water-soluble carbohydrate content does not improve the prediction). However the accuracy is only slightly better than that obtained from lignin and protein alone, which does not warrant the measurement of the hemicellulose and cellulose content.

In the analysis using detergents (VAN SOEST and WINE, 1968), hemicelluloses are estimated as the difference between neutral-detergent fibre (NDF) and aciddetergent fibre (ADF) and cellulose as the difference between ADF and lignin. This cellulose value clearly overestimates the cellulose content (table 3 ) by 15-20 per cent in grasses and 25-35 per cent in legumes. The hemicellulose value is misleading because it is subject to errors both in NDF and ADF, which are sometimes self-cancelling. Compared to the non-cellulosic polysaccharide content, the VAN SOEST hemicellulose is much lower for legumes and much higher for mature grasses. In a sequential procedure, the ADF is measured on the NDF. It is lower than the ADF measured directly, which results in a lower hemicellulose value; the acid insoluble lignin is greatly decreased and appears meaningless (RIQUeT, 1979). Procedural modifications to the detergent system and different sequences of analytical treatments have been proposed (VAN SOEST and RobertSON, 1980 ; FonNESBECK, 1976).

Summative equations including NDF, ADF and detergent lignin led to a more accurate prediction of forage digestibility over ADF alone (VAN SoEsT and RobertSOn, 1980 ; OSBOURn et al., 1971 ; AERTS et al., 1977a; 1977b). A more accurate prediction was obtained in the Netherlands (VAN DER KoELEN and VAN Es, 1973) from determining a neutral detergent residue and its anhydro-uronic and lignin contents according to the method of Gaillard and NiJKamP (1968).

\section{Conclusions}

What we need is a chemical method that would reproduce, at less proportionnally, the action of microbial enzymes on the cell-walls. It should dissolve the digestible cell-walls leaving as a residue the indigestible cell-walls. Attempts have been made using chemical treatments that dissolve the amorphous part of the cellulose, like cupriethylene diamine (DEHORITY and JoHNSON, 1964) or cadmium salts (Cadoxen) (JARRIGE, unpublished). They leave an empirical fibre which is not more closely related to digestibility than is crude fibre or ADF 
In fact, it seems very difficult to find a chemical agent that would dissolve the digestible cellulose without dissolving the major part of the indigestible hemicellulose, to estimate the indigestible cell-walls.

Such an estimation is easily obtained with the in vitro methods using rumen microorganisms or fungal cellulosic preparations (see OsBOURN and SIDDONS, 1980 and MARTIN and BARNES, 1980). It is the reason why these methods, especially the two-stage digestion technique of TILLEY and TERRY and its derivatives, give a more accurate prediction of forage digestibility than any single chemical estimates. However their use in routine laboratories is limited respectively by the need to maintain donor animals or by the variation in the activity of different sources of " cellulases ».

Chemical determinations of cell-wall fractions remain the basic methods for these laboratories. Crude fibre is useful for describing the variations of the cell-wall contents of temperate forages and predicting their digestibility. But it should be correctly used. Firstly, as any other fibre fraction, it must be determined in conjunction to a preliminary observation of the botanical composition, age and stage of growth of the forage and the climatic conditions. Secundly, prediction equations of the organic matter digestibility (and not dry matter) should be calculated for each species and cut (at least first cut and regrowths) and include the crude protein content and frequently quadratic termes (see DEMARQUILLY et al., 1980). This is possible because crude fibre has been measured in the thousands of digestibility trials carried out for many decades.

To counterbalance this immense historical advantage alternative methods to crude fibre must be superior if possible for all the criteria of evaluation : adaptation to routine, reproducibility, accuracy in the prediction of digestibility, and cost. Sequential analysis are too much time consuming; most lignin methods lack of reliability or reproducibility ; NDF is a poor predictor of digestibility. Only the $\mathrm{ADF}$ is liable to replace crude fibre. Although as empirical as is crude fibre, it is quicker and probably more reproducible and it allows a slightly more precise prediction of forage digestibility. These advantages have been considered sufficient by some people to recommand the replacement of crude fibre by ADF, or at least the determination of fibre by both methods " to gradually develop an adequate analytical base that will allow discontinuance of crude fibre as soon as possible (1) ).

However the shortcomings of ADF are yet so large that an other attitude is to wait for methods which would be decisively superior to crude fibre. The use of cellulolytic preparations offers the best possibilities in the near future.

Infrared reflectance spectrocopy (NORRIS et al., 1976) could be of value for large laboratories when the proper wavelengths have been identified for each forage group.

\section{Prediction of the protein value of forages}

\section{The nitrogenous substances of forages}

The nitrogenous substances of forages may be empirically divided by extraction with 70-80 per cent ethanol (possibly followed by a water extraction)

(1) From the recommandations of a workship held in Ottawa on "Standardization of analytical methodology for feeds" (Editors W. J. Pigden. C. C. Balch and M. Graham). 

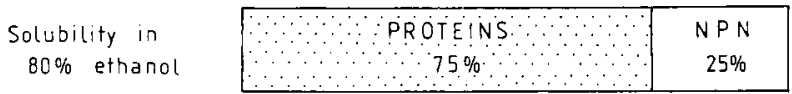

Solubility in artificial saliva

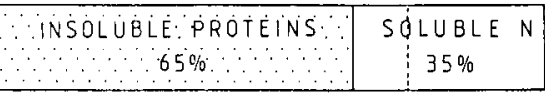

Degradability in

\begin{tabular}{|c|c|c|}
\hline UNDEGRADABLE & DEGRADABLE N \\
PROTEINS 42\% & $58 \%$ \\
\hline
\end{tabular}

FIG. 8. - Model of the repartition of the nitrogen fractions of a fresh forage.

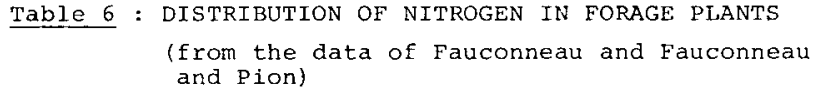

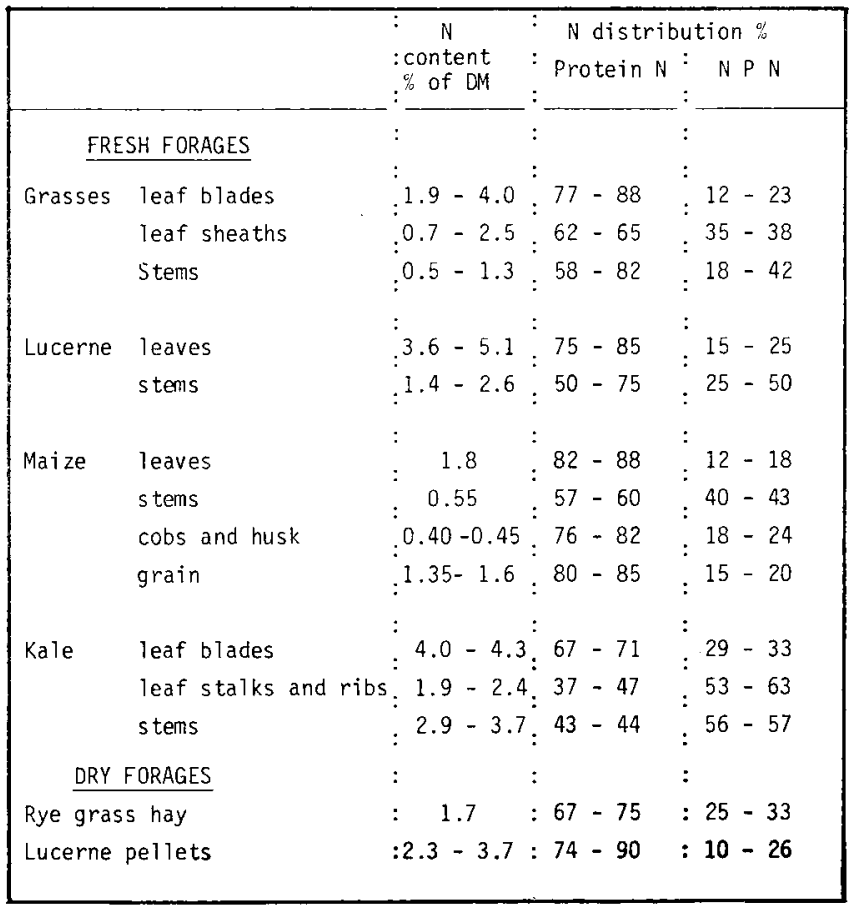

into two fractions (fig. 8) : the « non-protein » components (NPN) which are extracted and the " proteins " which normally are not extracted.

The free amino acids and their amides (glutamine, asparagine) are the major components of the NPN fraction in fresh forages, while low molecular weight peptides, bound amino acids, ureides, nucleotic and chlorophyll are minor components. They are mainly located in the vacuole. The proportion of NPN in total 
nitrogen is quite considerable and variable in fresh forages (table 6). It is particularly high in stems and in roots as well. The normal values in standing plants are 20-25 per cent in grasses and 25-30 per cent in legumes.

Proteins have been studied in the leaves of a few species (spinach, tobacco, pea, barley). Typical distribution of proteins in leaf cells is the following (BRADY, 1976) : 55-56 per cent in chloroplasts, 20-35 per cent in the cytoplasm, 5-7 per cent in mitochondria, 1-2 per cent in the nucleus and 1-2 per cent in cell wall. About half of the leaf proteins are extracted by low ionic strength neutral $\mathrm{pH}$ buffers and called " soluble ". The " insoluble " proteins are either in or associated with membranes.

The $\mathrm{N}$ distribution in forages is modified by processes of conservation. The plant enzymes cause extensive proteolysis (autolysis) during wilting and/or the early stages of ensilage (Gouet et al., 1965). Peptides and amino acids are the main end products of proteolysis. They increase the N P N content of hays and can be fermented by bacterial enzymes in the silo. The extent of proteolysis can be restricted by rapid acidification or by the addition of formaldehyde. The extensive breakdown of amino acids and amides to ammonia and undesirable products (amines...) can be prevented by controlling the growth of Clostridia and Enterobacteriaceae. High temperature dehydration of freshly cut herbage prevents proteolysis but overheating can induce Maillard reactions.

\section{Assessment of the protein value of forages}

In most countries the protein value of ruminant feeds has long been expressed as apparently digestible crude protein (DCP). The DCP content of forages can be predicted very accurately from the crude protein content (CP). For example, the general equation obtained at Theix on 1432 fresh forages is :

$$
\mathrm{DCP}=40.2+\Delta+0.939 \mathrm{CP}( \pm 4.8) \quad \mathrm{R}=0.996
$$

The contents are expressed as $\mathrm{g} / \mathrm{kg}$ organic matter (DemarquiLly et al., 1980). The value of $\Delta$ (from 4 to -5 ) depends on the forage species and the cut number. However, the apparently non-digestible protein can be increased by overheating in hays and silages and overdrying of dehydrated forages.

Though generally suitable for practical purposes, the DCP content is inadequate when grass silages, industrial non-protein sources or protected proteins are used. The actual protein value of a feed depends in fact on the amount (and relative proportion) of the amino acids absorbed in the small intestine, which originate from three sources : the dietary proteins which have escaped microbial degradation in the reticulo-rumen, the microbial proteins synthesised in the rumen and endogenous proteins. Systems based on these principles have recently been proposed in different countries, for example in the United Kingdom by the ARC (Roy et al., 1977) and in France by INRA (JARRIGE et al., 1978 ; VeriTE et al., 1979). They require a prediction of both the rumen degradability of feed $\mathrm{N}$ and the microbial protein synthesis in the rumen (see reviews by TAMmINGA (1979) and Verite (1980)) and knowledge of the digestibility of dietary and microbial proteins in the small intestine.

\section{Prediction of the $N$ degradability}

The undegraded dietary $\mathrm{N}$ is assessed indirectly and thus with a limited accuracy in the $\mathrm{N}$ flow entering the duodenum. Large variations between 
forages have been found (see data collected by Verite and PONCET in JARRIGE et al., 1978). The three categories of $\mathrm{N}$ components which are degraded in the rumen (fig. 8) are : 1) the NPN components, 2) the proteins soluble in the rumen fluid and 3) a fraction of the insoluble protein which is more slowly degraded. The proportions of the two first categories in the forage $\mathrm{N}$ can be considered to depend only on the forage characteristics as shown in table 6 for NPN. The proportion of the insoluble proteins which are degraded depends in addition on the environment in the rumen (rate of proteolysis...) and on the retention time in the rumen. Thus the extent of protein breakdown is reduced by grinding dry forages and increasing the level of intake.
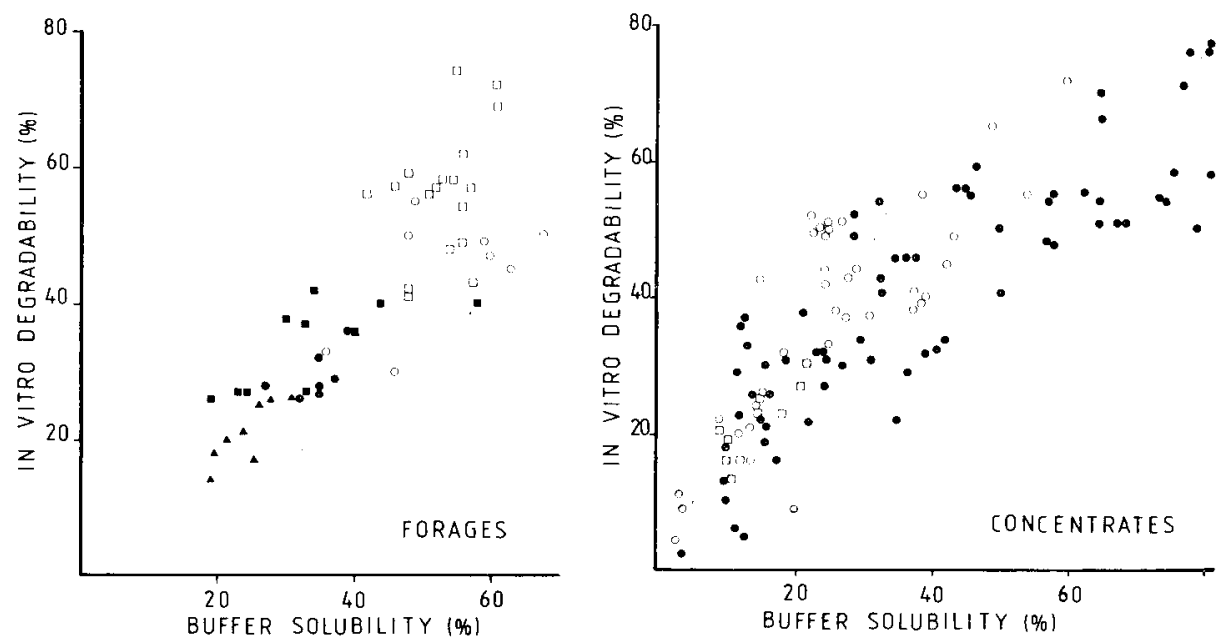

FIG. 9. - Relationship between $N$ solubility in an artificial saliva and in vitro $N$ degradation (measured by $\mathrm{NH}_{3}$ production during a $6 \mathrm{~h}$ incubation in whole rumen contents) (unpublished data of VERITE and JOURNET).

Forages: - grass, hays, $\nabla$ dehydrated lucerne, $\square$ maize silage, $\bigcirc$ grass silage.

Concentrates: - oil seeds and meals, $O$ cereals, sugar beet-pulps.

A variety of solvents has been used to predict $\mathrm{N}$ degradability : water, sodium chloride, diluted alkali, artificial saliva, phosphate buffer, phosphate bicarbonate buffer, autoclaved rumen fluid... (WALDO, 1978). Only limited comparisons of some of these laboratory procedures have been made (CRAWFORD et al., 1978 ; CroOKER et al., 1978; Waldo and GoeHring, 1979) Classification of feeds were roughly the same but significant interactions of feed by methods were observed. Solubility of forage $\mathrm{N}$ has been found moderately related $(\mathrm{R}=0.55)$ to in vivo degradability in the sole comparison available (G.R.I. 1977) and closely related to $\mathrm{N}$ disappearance in a dacron bag suspended in the rumen (CrAWFORD et al., 1978) or to $\mathrm{NH}_{3}$ production in an in vitro incubation with rumen digesta (Verite and Demarquilly, 1978) (fig. 9). The correlations between the solubility in a mineral buffer (WISE BURROUGHS) and the rumen degradation in the dacron bag depended on the length of the rumen incubation, being highest at $2 \mathrm{~h}$. for silages (0.94) and $4 \mathrm{~h}$. for hays (0.88) (CraWFORD et al., 1978).

Mineral buffers similar to artificial salivas can be considered to dissolve the NPN components and a fraction of the proteins which is closeley related to that 
soluble in the rumen fluid (fig. 8). Therefore, they are valuable in predicting the $\mathrm{N}$ degradability in the rumen. However, they cannot be very accurate predictors because they do not dissolve the fraction of the insoluble protein which is degradable. On the average, this fraction should equal 35 per cent of the insoluble protein. This value is based on multiple regression calculated by VERITE and PONCET relating the non-ammonia $N$ entering the duodenum (ND) to the daily intakes of digestible organic matter (DOMI) and of insoluble N (INI) (JARRIGE et al., 1978 - VERITE et al., 1979).

Thus, all the soluble $\mathrm{N}$ and 35 per cent of the insoluble $\mathrm{N}$ appear to have been degraded in the rumen :

$$
\begin{aligned}
\text { degradability } & =\text { solubility }+0.35(1-\text { solubility }) \\
& =0.65 \text { solubility }+0.35
\end{aligned}
$$

The relationship has been used in France to calculate the dietary protein escaping rumen degradation and hence the PDI value of the feedstuff (proteines réellement digestibles dans l'intestin grêle). Solubility was measured in a mineral buffer solution similar to saliva. However some values have been corrected when in disagreement with $\mathrm{N}$ degradation occuring in in vitro incubation with rumen digesta, which is considered as a reference method. Mean values of the $\mathrm{N}$ degradability of forages range from 0.50 to 0.70 for green herbage, from 0.45 to 0.60 for hays, dehydrated forages, from 0.60 to 0.80 for silages. It is worth mentionning that the $\mathrm{N}$ content of centrifuged silage juice is very close to the $\mathrm{N}$ soluble in artificial saliva.

Solubility methods using artificial salivas are less reliable than microbial methods (dacron bag, in vitro incubation) but they are more reproducible and adapted to routine. In spite of their shortcomings they provide a significant improvement in predicting the protein value of most feeds and a simple means of using the new protein systems. The replacement of total $\mathrm{N}$ by insoluble $\mathrm{N}$ increases accuracy in predicting the non ammonia $\mathrm{N}$ entering the duodenum (VERITE et al., 1979) and of the $N$ retention of growing cattle (WALDO and GoERING, 1979) and of sheep fed grass silages (GRENET et al., unpublished). A reduction in the forage $\mathrm{N}$ solubility has been related to the increase in the aminoacid supply to the animal obtained through dehydration or the use of silage additives such as formaldehyde (see review by BEEVER, 1980). Significant increases in milk yield have been obtained by formulating the diets acccording to the $\mathrm{N}$ insolubility of their ingredients (TAMmINGA, 1979).

However, there is a need for enzymatic methods which would match the adaptation to routine of solubility methods with the better relationships to in vivo degradation supplied by microbial methods.

\section{Prediction of microbial protein synthesis}

Once the supply in degradable $\mathrm{N}$ (as well as minerals and growth factors) is not limiting the quantity of protein synthesized by rumen microbes is related to the supply of available energy. Average values of $27-32 \mathrm{~g}$ of microbial $\mathrm{N}$ synthesized per $\mathrm{kg}$ of organic matter apparently digested in the rumen have been calculated from the in vivo data. Average values of 120-135 $\mathrm{g}$ of microbial protein per $\mathrm{kg}$ of apparently digestible organic matter ingested (DOMI) have been used to build the new systems (see VERITE et al., 1979). Therefore the yield of microbial protein allowed by the degradable energy of each forage can be calculated from its digestibility predictors (crude fibre, ADF..., crude protein...). 
However, large variations have been found between forages in the yield of microbial protein per $\mathrm{kg} \mathrm{DOM}$ (from $<75 \mathrm{~g}$ to $>150 \mathrm{~g}$ ). They partly arise from differences in the accuracy of measurement methods. But there are certainly actual differences between forages because of differences in their composition (relative proportions of water-soluble carbohydrates, cell-wall carbohydrates, soluble nitrogen...) and in their rate of degradation in the rumen. These chemical and physical properties can affect the parameters of the energetic efficiency of the rumen microbial population, that are the rate of growth and the maintenance requirement of the population, the $\mathrm{pH}$ and the dilution rate of the rumen fluid, the degree of coupling between ATP and $\mathrm{NH}_{3}$ production... (see HeSPELL and BRYANT, 1979). It can be hypothesized that young forages sustaining a dense microbial population, which has a high growth rate and flows rapidly out of the rumen, are likely to promote greater efficiency of energy utilisation for microbial protein synthesis.

\section{Conclusions}

The tremendous amount of research that has been carried out over the past 15 years, has led to a satisfactory understanding of the major aspects of nitrogen digestion and metabolism in ruminants. The physiological framework is now strongly established but much remains to be done to improve our knowledge on the extent of dietary $\mathrm{N}$ degradation in the forestomachs, microbial protein synthesized or entering the duodenum, true digestibility of dietary and microbial proteins in the small intestine, endogenous protein and urea secretion and recycling, requirements of the animals...

Two contrasting positions regarding the application of present knowledge and the replacement of the DCP system by new systems arise :

- one can stress on the insufficiencies of our knowledge and wait for them to be overcome before adopting or building new systems ;

- one can stress the importance and potential of present knowledge for an immediate application and incorporate it into new systems, even if many values are temporary.

The latter position has been adopted by research groups in different countries, U.S.A. (Burroughs et al., 1975; Satter and Roffler, 1975), United Kingdom (Roy et al., 1977), Western Germany (KaufmanN, 1977), France (Jarrige et al., 1978 ; VERITE et al., 1979). In spite of being incomplete at present, the new systems overcome most of the DCP system shortcomings. For example, the French PDI system allows : $1^{\circ}$ ) a better assessment of the potential protein values of feeds, especially of grass silages $; 2^{\circ}$ ) a prediction of the associative effects between feeds $; 3^{\circ}$ ) an easy calculation of the quantity of urea, or other forms of non-protein nitrogen that would be useful ; $4^{\circ}$ ) a prediction of the response to a supply of protected proteins or amino acids and $5^{\circ}$ ) a better nutrition of the rumen microorganisms.

However, it is fully recognized that in many practical circumstances little error may be incurred by using the DCP system with proper corrections for NPN rich feedstuffs and diets. 


\section{References}

Aerts J.V., de Brabander D.L., Cottyn B.G., Carlier L.A., Buysse F.X., 1977. Contribution à la détermination de la valeur alimentaire des fourrages grossiers. V. Estimation de la digestibilité et de la valeur énergétique à l'aide des fractions de la paroi cellulaire et des «summative equations 》de Van Soest. Revue Agriculture, 30, 933-955.

Aerts J.V., de Brabander D.L., Cottyn B.G., Buysse F.X., 1977b. Comparison of laboratory methods for predicting the organic matter digestibility of forages. Anim. Feed. Sci. Technol., 2, 337-349.

Aerts J.V. de Brabander D.I., Cottyn B.G., Buysse F.X., Carlier L.A., Moermans R.J., 1978. Some remarks on the analytical procedure by Van Soest for the prediction of forage digestibility. Anim. Feed Sci. Technol., 3, 309-322.

AKIN D.E., 1979. Microscopic evaluation of forage digestion by rumen microorganisms. A review. J. Anim. Sci., 48, 701-710.

Alderman G., Collins F.C., Dougall H.W., 1971. Laboratory methods of predicting feeding value of silage. J. Br. Grassl. Soc., 26, 109-111.

BaILeY R.W., 1964. Pasture quality and ruminant nutrition. I. Carbohydrate composition of rye grass varieties grown as sheep pastures. N.Z.J. Agric. Res., 7, 496-507.

Bailey R.W., Ulyatt M.J., 1970. Pasture quality and ruminant nutrition. 2. Carbohydrate and lignin composition of detergent-extrated residues from pastures grasses and legumes. N.Z.J. A gric. Res., 13, 591-604.

BAILEY R.W., 1973. Structural carbohydrates. In Chemistry and biochemistry of herbage, 1. 157-211 (Ed. G. Butler and R.W. Bailey). Academic Press - New York.

BARNES R.F., 1973. Laboratory methods for evaluating feeding value of herbage. In Chemistry and biochemistry of herbage, 3, p 179-214. (Ed. G. Butler and R.W. Bailey). Academic Press. New York.

BEEvER D.E., 1980. The utilisation of protein in conserved forage. In Forage conservation in the 80's. (British Grassland Society C. Thomas editor) 131-143. Occasional Symposium $\mathrm{n}^{\circ} 11$.

Charley-Lery Genevieve, François A.C., Leroy A.M., 1972. L'analyse des aliments destinés aux animaux et l'interprétation des résultats qu'elle fournit. Ann. Zootech. 1, 45-63.

Clancy M.J., Wilson R.K., 1966. Development and application of a new chemical method for predicting the digestibility and intake of herbage samples. Proc. 10th Inter. Grassl. Cong., Helsinki., p. 445-453.

Colburn M.W., Evans J.J., 1967. Chemical composition of the cell-wall constituent and acid-detergent fiber fractions of forages. J. Dairy Sci., 50, 1130-1135.

Crampton E.W., Maynard L.A., 1938. The relation of cellulose and lignin content to the nutritive value of animal feeds. J. Nutr., 15, 383-395.

Crawford R.J., Hoover W.H., Sniffen C.J., Crooker B.A., 1978. Degradation of feedstuff nitrogen in the rumen vs nitrogen solubility in three solvents. J. Anim. Sci, 46, 1768-1775.

Crooker B.A., Sniffen C.J., Hoover W.H., Johnson L.L., 1978. Solvents for soluble nitrogen measurements in feedstuffs. J. Dairy Sci., 61, 437-447.

Dehority B.A., Johnson R.R., 1964. Estimation of the digestibility and nutritive value of forages by cellulose and dry matter solubility methods. J. Anim. Sci., 23, 203-207.

Deriaz R.E., 1961. Routine analysis of carbohydrates and lignin in herbage. J. Sci. Fd. Agric., 12, 152-160.

DeInUM B., 1971. Prediction of forage digestibility from some laboratory procedures. 2. Comparison of in vivo digestibility at two Institutes. Neth. J. Agric. Sci., 19, $106-113$.

Demarquilly C., Andrieu J., Sauvant D., DulPhy J.P., 1978. Composition et valeur nutritive des aliments. In Alimentation des Ruminants. pp. 459-518. Ed. INRA. Publ. Route de Saint Cyr. 78000 Versailles.

Demarquilly C., Chenost M., Sauvant D., 1980. Simple methods to predict feeding value : Applied aspects. In Energy and protein feeding Standards applied to the rearing and finishing of beef cattle. Ann. Zootech. 29, 351-362.

EDWARDS C.S., 1973. Determination of lignin and cellulose in forages by extraction with triethylene glycol. J. Sci. Fd. Agric., 24, 381-388. 
Fauconneau G., Jarrige R., 1957. Composition chimique et valeur nutritive de l'herbe. Bull. Tech. Ing. Agric., 118, 173-214.

FonNEsBeck P.V., 1976. Estimating nutritive value from chemical analyses. In Proc. First Inter. Symposium Feed composition, animal nutrient requirements, and computerization of diets. (Ed. J.V. Fonnesbeck, L.E. Harris and L.C. KeArL) 219-227. Utah State University, Logan, Utah.

Gaillard B.D.E., 1958. A detailed summative analyse of crude fibre and nitrogen-free extractives fractions of roughages. 1. Proposed scheme of analysis. J. Sci. Fd. Agric., 3, 170-177.

Gordon A.J., 1975. A comparison of some chemical and physical properties of alkali lignins from grass and lucerne hays before and after digestion by sheep. J. Sci. Fd. Agric. 26, $1551-1559$.

Gouet Ph., Fatianoff Nathalie, Zelter S.Z., Durand Michelle, Chevalier R., $1965 . \quad$ Influence de l'élévation du taux de matière sèche sur l'évolution biochimique et bactériologique d'une luzerne conservée par ensilage. Ann. Biol. anim. Bioch. Biophys., 5, 79-100.

Grenet Elizabeth, 1966. Les particules végétales des fécès du Mouton. Ann. Zootech., 15. 303-312.

Guillemet R., Preceptis P., 1942. Le dosage de la cellulose par dissolution formique de l'amidon et des protéines. C.R. Acad. Agric., France, 28, 383.

Guillemet R., JACQUOT R., 1943. Essai de détermination de l'indigestible glucidique. $C$. R. Accid. Sci., 21 $6,508-510$.

Hallsworth E.G., 1950. The crude fibre determination and its alternatives. Agric. Prog., 25, 39-49.

HARWOOD V.D., 1954. Analytical studies on the carbohydrates of grasses and clovers. V. Development of a method for the estimation of cell-wall polysaccharides. J. Sci. Fd. Agric., 5, 270-275.

HeSPej.L E.B., Bryant M.P., 1979. Efficiency of rumen microbial growth : influence of some theorical and experimental factors on YATP. J. Anim. Sci., 49, 1640-1659.

JARRIGE R., 1961. Analyse des constituants glucidiques des plantes fourragères. I. Fractionnement des constituants de la membrane par des hydrolyses acides. Ann. Biol. anim. Bioch. Biophys., 1, 163-212.

JARrige R., 1961. Analyse des constituants glucidiques des plantes fourragères. II. La lignocellulose : composition, dosage et comparaison avec la cellulose brute. A mm. Biol. anim. Bioch. Biophys., 1, 421-447.

JARRIGE R., 1963. Les constituants membranaires des plantes fourragères. Ann. Biol. anim. Bioch., Biophys., 3, 143-190.

JARRIGE R., Minson D.J., 1964 . Digestibilité des constituants du ray-grass anglais S 24 et du dactyle S 37, plus spécialement des constituants glucidiques. Ann. Zootech., 13, 117-153.

JARrige R., Thivend P., 1969. Action d'une cellulase fongique sur les membranes et son intérêt pour prévoir la digestibilité des plantes fourragères. Ann. Biol. anim. Bioch. Biophys., 9, 171-190.

Jarrige R., Thivend P., Demarquiliy C., 1970. Development of a cellulolytic enzyme digestion for predicting the nutritive value of forages. Proc. XI Int. Grassl. Congr. Queensland, Australia, pp. 762-766.

JaRrige R., Journet M., Verite R., 1978. L'azote. In « L'Alimentation des Ruminants» pp. 89-128. Ed. INRA, Publ. Route de Saint-Cyr, 78000 Versailles.

JoURnet M., JARrige R., 1962. Analyse des constituants glucidiques des plantes fourragères. III. Etudes sur je dosage de la lignine. Ann. Biol. anim. Biophys., 2, 223-250.

KeSTING U., 1978. Uber neuere Ergebnisse einer vereinfachten in-vitro - Methode zur Schätzung der Verdaulichkeit der organischen Substanz chne Pansensaft. Arch. Tierernährung., 28, 1978, 491-497.

Kim T.J., Gillingham J.T., I.oadhol C.B., 1967. Difference in composition between crude fiber and acid-détergent fiber. J. Assoc. Off. Anal. Chem., 50, 340-343.

KirChGesSNer M., Kellner R.J., $1977 . \quad$ Zur Schätzung der unsetzbaren energie von grün und rauhfutter mit einfachen kenndaten. Z. Tierphysiol. Tierernähr. Futtermittelkde, 38, 297-301.

Kivimae A., 1959. Chemical composition and digestibility of some grassland crops. Acta Agr. Scand. Supl. 5. 1-42.

Kurschner K., Hoffer A., 1929. A new process for the determination of cellulose in wood and pulp. Tech. chem. Poper. Zellstoff. Fab., 26, 125. 
MC LEOD M.N., Minson D.J., 1971. The error in predicting pasture dry-matter digestibility from four different methods of analysis for lignin. J. Br. Grassl. Soc., 26, 251-255.

MC LEOD M.N., Minson D.J., 1972. The effect of method determination of acid-detergent fibre on its relationship with the digestibility of grass. J. Br. Grassl. Soc., 27, 23-27.

MC LEOD M.N., Minson D.J., 1974. The accuracy of predicting dry matter digestibility of grasses from lignin analysis by three different methods. J. Sci. Fd. Agric., 25, 907-911.

Minson D.J., 1976. Relation between digestibility and composition oí' feed. In Carbohydrate research in plant and animals. 101-114. Landbouwhogeschool Wageningen, The Netherlands. Misc. Papers. 12.

Morrison I.M., 1972. A semi-micro method for the determination of lignin and its use in predicting the digestibility of forage crops. J. Sci. Food Agric., 23, 455-467.

MORRISON I.M., 1973. A note on the evaluation of the nutritive value of forage crops by the acetyl bromide technique. J. Brit. Grassld. Soc., 28, 153-154.

MorRison I.M., 1976. New laboratory methods for predicting the nutritive value of forage crops. Wld. Rev. Anim. Prod., 12, 75-82.

Norris K.M., Barnes R.F., MOORE J.E., Shenk J.S., 1976. Predicting forage quality by infrared reflectance spectroscopy. J. Anim. Sci., 43, 889-897.

Norman A.G., 1935. The composition of crude fibre. J. Agric. Sci., 25, 529-540.

Norman A.G., Jenkins S.H., 1933. A new method for the determination of cellulose, based upon observations on the removal of lignin and other incrusting substances. Bioch. J., 27, 818-831.

Osbourn D.F., Terry R.A., Outen G.E., Cammell S.B., Lansley P.R., 1971. Chemical and in vitro digestion procedures for prediction of the digestibility of forage crops by sheep. Proc. Nutr. Soc., 31, 85 A.

Osbourn D.F., Terry R.A. Outen G.E., Cammell S.B., 1976. The significances of a determination of cell walls as the rational basis for the nutritive evaluation of forages. Proc. XII Int. Grassld Congr., Moscow, 3, 374-380.

OsBourn D.F., 1978. Principles governing the use of chemical methods for assessing the nutritive value of forages : a review. Anim. Feed Sci. Technol., 3, 265-275.

OSBOURN D.F., SiDDONS R.C., 1980. Enzymatic methods to predict the value of energy and protein in feedingstuffs. In Energy and protein feeding Standards applied to the rearing and finishing of beef cattle. Ann. Zootech., 29, 325-336.

Paloneimo L., 1945. Determination of total quantity of cell wall constituents in foods and feeds. Maataloust. Aikakaustk. 17, 19-21.

Paloheimo L., Paloheimo I., 1948. On the estimation of the total of vegetable membrane substances. Maataloust. Aikakausk. 21, 1-15.

Pichard G., Van Soest P.J., 1977. Protein solubility of feeds. Proc. Cornell Nutr. Conf., p. 91-98.

RIQUET Anne-Marie, 1979. Etude des constituants membranaires des produits végétaux destinés à l'alimentation animale. Signification et limites des principales méthodes de dosage. Thèse Doctorat $3^{\circ}$ cycle, Université de Paris XI, 85 pp.

Roy J.H.B., Balch C.C., Miller E.R., Orskov E.R., Smith R.H., 1977. Calculation of the N-requirement for ruminants from nitrogen metabolism studies. In Protein metabolism and Nutrition. pp. 126-129 EAAP Publ. $\mathrm{n}^{\circ}$ 22. Center for Agricultural Publishing and Documentation. Wageningen.

SAlo Maria-Lisa, 1965. Determination of carbohydrates fractions in animal foods and faeces. Acta Agral. fenn., 105, pp. 102.

Southgate D.A.T., 1969. Determination of carbohydrates in foods. II. Unavailable carbohydrates. J. Sci. Fid. Agric., 20, 331-335.

Sullivan J.T., 1964 . Chemical composition of forages in relation to digestibility in ruminant ARS 34-62. U.S. Department of Agriculture. 58 pp.

TAmminga S., 1979. Protein degradation in the forestomachs of ruminants. J. Anim. Sci., 49, 1615-1630.

Theander O., Aman P., 1980. Chemical composition of some forages and various residues from feeding values determinations. J. Sci. Fd Agric., 31, 31-37.

VAN DeR Koelen C.J., VAN Es A.J.H., 1973. A comparison of some laboratory techniques for the estimation of the digestibility of the organic matter in forage samples. Neth. J. Agric. Sci., 21, 199-205.

VAN SOEST P.J., 1963. Use of detergents in the analysis of fibrous feeds. II. A rapid method for the determination of fiber and lignin. J. Ass. off. agric. Chemic., 46, 829-835. 
VAN SoEsT P.J., 1965. Use of detergents in the analysis of fibrous foods. III. Study of the effects of heating and drying on yield of fiber and lignin in forages. J. Assoc. Off. Agric. Chem., 48, 785-790.

VAN SoEst P.J., 1967. Development of a comprehensive system, of feed analyses and its application to forages. J. Anim. Sci., 26, 119-128.

VAN Soest P.J., WINE R.H., 1967. Use of detergents in the analysis of fibrous feeds. IV. Determination of plant cell-wall constituents. J. Ass. off Agric. Chem., 50, 50-55.

Van Soest P.J., WINE R.H., 1968. The determination of lignin and cellulose in acid-detergent fibre with permanganate. J. Ass. Off. Agric. Chemic., 51, 780-785.

VAN SOEST P.J., Jones L.H.P., 1968. Effect of silica in forages upon digestibility. J. Dairy Sci., 51, 1644.

VAN Soest P.J., Mertens, 1977. Analytical parameters as guides to forage quality. In Proc. Int. Meeting on animal production from temperate grasslands Dublin, 50-52, (Ed. B. Gilseman).

VAN SOEST P.J., RoBERTSON, 1980. Systems of analysis for evaluating fibrous feeds. In Standardization of analytical methodology for feeds, 49-60. (Editors : W.J. Pigden, CC. Balch, and M. Graham). International development Research Centre. Ottawa.

Verite R., Demarquilly C., 1977. Qualité des matières azotées des aliments pour ruminants. In «La Vache laitière » pp. 143-157. Ed. INRA. Publ. Route de Saint-Cyr, 78000 Versailles.

Verite R., Journet M., JARrige R., 1979. A new system A for the protein feeding of ruminants : the PDI system. Livest. Prod. Sci., 6, 349-367.

VERITE R., 1980. Appreciation of the nitrogen value of feeds for ruminants. In Standardization of analytical methodology for feeds, 87-96. (Editors : W.J. Pigden, C.C. Balch, and M. Graham) International development Research Centre. Ottawa.

Waite R., Gorrod A.R.N., 1959. The comprehensive analysis of grasses. J. Sci. Fd. Agric., 6, 317-326.

WALDO D.R., 1978. Concepts, evaluations and prediction of nitrogen utilization by ruminants. Proc. Georgia Nutr. Conf. for the feed industry, 13-26.

WALDO D.R., GoERING H.K., 1979. Insolubility of proteins in ruminant feeds by four methods. J. Anim. Sci., 49, 1560-1568.

Walker D.M., HePburn W.R., 1955. Normal-acid fibre : a proposed analysis for the evaluation of roughages. I. The analysis of roughages by the normal-acid fibre method, and its use for predicting the digestibility of roughages by sheep. Agric. Progress., 30, 118-119. 